Brit. J. industr. Med., 1963, 20, 63.

MISCELLANEA

\title{
Toxicity of Tetramethyl Lead Solutions to Mice and Rabbits \\ BY
}

\author{
N. CASTEllino, A. ROSSI, and R. MOLÉ \\ From the Institute of Industrial Medicine of Naples University
}

(RECEIVED FOR PUBLICATION JANUARY 30, 1962)

A solution of tetramethyl lead, used as an antiknock agent in gasoline, was given by injection and inhalation to mice and by injection to rabbits. The signs of poisoning are described. Deaths might be delayed until 10 days after dosing.

Tetramethyl lead (TML) has recently been adopted as an antiknock substance in gasoline. In some industries, tetramethyl lead has been substituted for tetraethyl lead (TEL) mixture or "ethylfluid". This recent development is the result of technical research which has shown that there is a more uniform octane distribution in all light and heavy fractions of gasoline in the combustion cylinders with the tetramethyl lead mixture.

The TML mixture used by us in this work was put at our disposal by a local firm and is a red liquid with a characteristic aromatic odour, insoluble in water but soluble in ethyl alcohol, ether, and chloroform. It has a specific gravity $\left(\right.$ at $+20^{\circ} \mathrm{C}$.) of 1.5 and vapour pressure (at $20^{\circ} \mathrm{C}$.) $36 \mathrm{~mm}$. $\mathrm{Hg}$. The composition of this TML mixture found on analysis is given in Table 1.

\section{Methods}

Toxicity to Mice.-Swiss albino mice weighing between 19 and $23 \mathrm{~g}$. were used. The $\mathrm{LD}_{50}$ has been determined by subcutaneous administration of the TML mixture, diluted in ethyl alcohol and water $(7: 3$ to $5: 5)$, and the dilutions have been calculated so that each animal received $0.01 \mathrm{ml}$. of the final solution per $\mathrm{g}$. body weight.

The doses administered ranged from $20 \mathrm{mg}$. to $1200 \mathrm{mg}$./ TML $/ \mathrm{kg}$. A series of 10 and six control mice received $0.01 \mathrm{ml} . / \mathrm{g}$. ethyl alcohol and water of either a $7: 3$ or $5: 5$ mixture respectively.

The lethal concentration $\left[\mathrm{g} . / \mathrm{m}^{3} \times\right.$ time $\left.(\mathrm{min}).\right]\left(\mathrm{LCt}_{50}\right)$ was determined by a single exposure of 30 minutes duration in a cage containing the TML mixture. In a series of 69 treated mice, their weights in each group differed by less than $3 \mathrm{~g}$. The concentrations of TML mixture used were calculated to be between 1.2 and $40 \mathrm{~g} . / \mathrm{m}^{3}$, though the presence of variable residues meant that the actual concentration was lower than those calculated.

The inhalation apparatus consisted of a cylindrical metal cage of $0.288 \mathrm{~m}^{3}$ volume $(\mathrm{r}=35 \mathrm{~cm} ., \mathrm{h}=75 \mathrm{~cm}$.) having two holes at opposite ends. An air flow of 740 1./hour was generated by a compressor. The air was heated by passing through a double-walled glass tube with an electrical resistance. The glass tube ended, through a capillary tube, in a dilated bulb into which the TML mixture was added dropwise. The toxic vapours were conveyed to the cage through a short silicone tube. Before each intoxication the cage was flushed for one hour with air containing the same concentration of toxic vapour as that to which the animals were to be exposed.

Calculations for determining the $\mathbf{L D}_{50}$ and $\mathbf{L C t}_{\mathbf{5 0}}$ values were carried out by the "probits" method; fiducial limits are given.

Toxicity to Rabbits.-Two groups of four rabbits each have been treated. In both groups the undiluted TML mixture was injected subcutaneously. The first group received $400 \mathrm{mg} . / \mathrm{kg}$. and the second $800 \mathrm{mg} . / \mathrm{kg}$.

\section{Results}

Toxicity to Mice.-The number of deaths occurring during the first six hours, three days, and 10

TABLE 1

COMPOSITION OF TETRAMETHYL LEAD MIXTURE

\begin{tabular}{l|c|c|c}
\hline \multicolumn{1}{c|}{ Compound } & $\begin{array}{c}\text { Molecular } \\
\text { Weight }\end{array}$ & $\begin{array}{c}\text { Specific } \\
\text { Gravity }\end{array}$ & Vol. \% \\
\cline { 1 - 2 } Tetramethyl lead $\left(\mathrm{CH}_{3}\right)_{4} \mathrm{~Pb}$ & $267 \cdot 37$ & 1.99 & 33.7 \\
Ethylene dibromide $\mathrm{CH}_{2} \mathrm{Br}_{2} \mathrm{CH}_{2} \mathrm{Br}$ & 187.88 & 2.16 & 10.8 \\
Ethylene dichloride $\mathrm{CH}_{2} \mathrm{Cl}_{\mathrm{CH}_{2}} \mathrm{Cl}$ & 96.97 & 1.25 & 19.9 \\
Toluene, dyes, impurities & - & - & 35.6 \\
\hline
\end{tabular}


TABLE 2

DEATHS AMONG MICE RECEIVING TML MIXTURE BY INJECTION (Deaths/Number injected)

\begin{tabular}{|c|c|c|c|c|c|c|c|c|c|c|c|c|c|c|c|c|c|c|c|c|c|c|c|c|c|c|}
\hline \multirow{2}{*}{$\begin{array}{c}\text { Dose } \\
\text { (mg./ } \\
\text { kg.) }\end{array}$} & \multicolumn{11}{|c|}{ Time After Injection (hours) } & \multicolumn{15}{|c|}{ Time After Injection (days) } \\
\hline & 6 & 24 & 36 & 48 & 60 & 72 & 84 & 96 & 108 & 120 & 132 & 6 & 7 & 8 & 9 & 10 & 11 & 12 & 13 & 14 & 15 & 16 & 17 & 18 & 19 & 20 \\
\hline $\begin{array}{r}\text { Alcoh } \\
1200 \\
1000 \\
800 \\
700 \\
600 \\
500 \\
400 \\
300\end{array}$ & 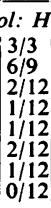 & $\begin{array}{l}I_{2} \mathrm{O}(7 \\
\mid \begin{array}{l}8 / 9 \\
5 / 12 \\
1 / 12 \\
3 / 12 \\
4 / 12 \\
2 / 12 \\
2 / 12\end{array}\end{array}$ & $\begin{array}{l}: 3) \\
\mid 9 / 9 \\
989 \\
8 / 12 \\
2 / 12 \\
4 / 12 \\
4 / 12 \\
4 / 12 \\
3 / 12\end{array}$ & $\mid \begin{array}{l} \\
8 / 12 \\
6 / 12 \\
9 / 12 \\
5 / 12 \\
6 / 12 \\
5 / 12\end{array}$ & $\begin{array}{c}10 / 12 \\
9 / 12 \\
10 / 12 \\
8 / 12 \\
9 / 12 \\
8 / 12\end{array}$ & $\begin{array}{r}12 / 12 \\
12 / 12 \\
12 / 12 \\
10 / 12 \\
9 / 12 \\
8 / 12\end{array}$ & \begin{tabular}{|r|} 
\\
$12 / 12$ \\
$10 / 12$ \\
$9 / 12$
\end{tabular} & \begin{tabular}{|l|}
$12 / 12$ \\
$11 / 12$
\end{tabular} & $12 / 12$ & & & & & & & & & & & & & & & & & \\
\hline Ethyl & $\begin{array}{l}\text { Alcol } \\
0 / 10\end{array}$ & $\begin{array}{l}\text { hol: } H \\
\mid 1 / 10\end{array}$ & $\begin{array}{l}\mathrm{H}_{2} \mathrm{O} \\
\mid 2 / 10\end{array}$ & $\begin{array}{l}(7: 3) \\
|2 / 10|\end{array}$ & $3 / 10$ & $3 / 10$ & $3 / 10$ & $3 / 10$ & $3 / 10$ & $3 / 10$ & $3 / 10$ & $4 / 10$ & $4 / 10$ & $4 / 10$ & $4 / 10$ & $5 / 10$ & $5 / 10$ & $5 / 10$ & $5 / 10$ & $6 / 10$ & $6 / 10$ & & & & & \\
\hline Alcoh & ol: $H$ & $\mathrm{I}_{2} \mathrm{O}(5$ & $: 5)$ & & & & & & & & & & & & & & & & & & & & & & & \\
\hline $\begin{array}{r}150 \\
80 \\
40 \\
20\end{array}$ & $\begin{array}{l}0 / 12 \\
0 / 12 \\
0 / 9 \\
0 / 6\end{array}$ & $\left|\begin{array}{l}1 / 12 \\
0 / 12 \\
0 / 9 \\
0 / 6\end{array}\right|$ & $\mid \begin{array}{l}1 / 12 \\
1 / 12 \\
0 / 9 \\
0 / 6\end{array}$ & $\mid \begin{array}{l}1 / 12 \\
1 / 12 \\
0 / 9 \\
0 / 6\end{array}$ & $\begin{array}{l}1 / 12 \\
1 / 12 \\
0 / 9 \\
0 / 6\end{array}$ & $\begin{array}{l}3 / 12 \\
1 / 12 \\
1 / 9 \\
0 / 6\end{array}$ & $\begin{array}{l}4 / 12 \\
1 / 12 \\
1 / 9 \\
1 / 6\end{array}$ & $\begin{array}{l}4 / 12 \\
3 / 12 \\
2 / 9 \\
1 / 6\end{array}$ & $\begin{array}{l}4 / 12 \\
3 / 12 \\
3 / 9 \\
2 / 6\end{array}$ & $\begin{array}{l}4 / 12 \\
4 / 12 \\
3 / 9 \\
2 / 6\end{array}$ & $\begin{array}{l}6 / 12 \\
5 / 12 \\
3 / 9 \\
2 / 6\end{array}$ & $\begin{array}{l}8 / 12 \\
6 / 12 \\
4 / 9 \\
2 / 6\end{array}$ & $\begin{array}{l}8 / 12 \\
6 / 12 \\
4 / 9 \\
2 / 6\end{array}$ & $\begin{array}{l}8 / 12 \\
8 / 12 \\
5 / 9 \\
2 / 6\end{array}$ & $\begin{array}{l}8 / 12 \\
8 / 12 \\
6 / 9 \\
2 / 6\end{array}$ & $\begin{array}{l}8 / 12 \\
9 / 12 \\
7 / 9 \\
2 / 6\end{array}$ & $\begin{array}{r}8 / 12 \\
11 / 12 \\
7 / 9 \\
2 / 6\end{array}$ & $\mid \begin{array}{c}8 / 12 \\
12 / 12 \\
7 / 9 \\
3 / 6\end{array}$ & $\begin{array}{l}9 / 12 \\
7 / 9 \\
3 / 6\end{array}$ & $\begin{array}{c}10 / 12 \\
7 / 9 \\
3 / 6\end{array}$ & $\mid \begin{array}{c}10 / 12 \\
8 / 9 \\
3 / 6\end{array}$ & $\begin{array}{c}11 / 12 \\
8 / 9 \\
3 / 6\end{array}$ & $\begin{array}{c}12 / 12 \\
8 / 9 \\
4 / 6\end{array}$ & $\begin{array}{l}9 / 9 \\
4 / 6\end{array}$ & $4 / 6$ & $4 / 6$ \\
\hline Ethyl & $\begin{array}{l}\text { Alcoh } \\
0 / 6\end{array}$ & $\begin{array}{l}\text { hol: } H \\
|0 / 6|\end{array}$ & $\begin{array}{l}y_{2} O \\
0 / 6\end{array}$ & $\begin{array}{l}(5: 5) \\
0 / 6\end{array}$ & $0 / 6$ & $0 / 6$ & $0 / 6$ & $0 / 6$ & $0 / 6$ & $0 / 6$ & $0 / 6$ & $0 / 6$ & $0 / 6$ & $0 / 6$ & $0 / 6$ & $0 / 6$ & $0 / 6$ & $1 / 6$ & $1 / 6$ & $2 / 6$ & $2 / 6$ & $2 / 6$ & $2 / 6$ & $2 / 6$ & $2 / 6$ & $2 / 6$ \\
\hline
\end{tabular}

days after subcutaneous injection is given in Table 2. The $L^{2} D_{50}$ values calculated were $1173 \mathrm{mg}$. $/ \mathrm{kg}$. (1117 to 1230 ), $224.1 \mathrm{mg} . / \mathrm{kg}$. (221.5 to 226.9 ), and $31.11 \mathrm{mg}$. $/ \mathrm{kg}$. (19.94 to 43.52$)$ respectively. Deaths at the first and tenth day after exposure to the vapour of the toxic mixture are given in Table 3 , and the $\mathrm{LCt}_{50}$ values were $40.8 \mathrm{~g} . / \mathrm{m}^{3}(36.4$ to $45 \cdot 8)$ and $8.51 \mathrm{~g} . / \mathrm{m}^{3}$ ( $4 \cdot 14$ to $\left.13 \cdot 36\right)$ respectively.

Toxicity to Rabbits.-Animals receiving $400 \mathrm{mg}$./ kg. of TML mixture died within three to six days after the injection, and those receiving $800 \mathrm{mg} . / \mathrm{kg}$. died within 18 to 24 hours after the injection.

Signs of Poisoning.-The following signs were observed in mice receiving more than $300 \mathrm{mg}$. $/ \mathrm{kg}$. by subcutaneous injection: hyperexcitability; 24 hours after injection frequent muscular quiverings developed, but paresis of the hind limbs was occasionally seen and was probably due to the injection trauma. No signs of poisoning were seen in animals given smaller doses of TML mixture. Animals given the $7: 3$ ethyl alcohol : water mixture showed narcosis preceded and followed by some degree of excitability. Less marked effects were seen in animals given the 5:5 ethyl alcohol and water mixture. Delayed deaths occurred in some animals of both groups as shown in Table 2 .

In mice exposed to TML mixture vapours the following changes were observed: at the end of exposure to concentrations varying from 36 to $40 \mathrm{~g}$./ $\mathrm{m}^{3}{ }^{3}$, severe drowsiness was seen in most animals and hyperexcitability in others $(30 \%)$. All animals showed strong motor excitability at the end of exposure to 12 to $24 \mathrm{~g} . / \mathrm{m}^{3}$ and after a further 36 hours light quiverings and myoclonus developed. After exposure to 6 to $8.3 \mathrm{~g} . / \mathrm{m}^{3}$ slight excitation was seen until death. No symptoms were observed in animals exposed to 1.2 to $2 \mathrm{~g}$. $/ \mathrm{m}^{3}$.

In the rabbits given $800 \mathrm{mg} . / \mathrm{kg}$. of TML mixture no signs of poisoning that could be related to an excitation or inhibition of the central nervous system were seen. A slight excitability was observed in rabbits 24 to 48 hours after receiving $400 \mathrm{mg}$. $/ \mathrm{kg}$.

\section{Discussion}

At present little is known of the toxicity of the TML mixture. However, something is known of the individual toxicity of the main components of the mixture.

Tetramethyl lead (TML).-Cremer and Callaway (1961) have recently shown that tetramethyl lead is less toxic than tetraethyl lead. The $L D_{50}$ for TML in the rat after oral administration was found to be $109 \cdot 3 \mathrm{mg} . / \mathrm{kg}$. $(77 \cdot 4$ to $154 \cdot 5)$. Comparison of the toxicity of the two compounds by inhalation showed that TML was one-tenth as toxic as TEL. Signs of poisoning analogous to those seen after trimethyl, triethyl, and tetraethyl lead were only found after giving high oral doses of TML. Based on the earlier studies of Cremer (1959) the relatively low toxicity of TML was thought to be due to the slow rate of conversion of tetramethyl lead to trimethyl lead since it is the latter compound that is an active inhibitor of metabolic processes of the central nervous system (Cremer and Callaway, 1961).

Salvi and Gherardi (1961) found an $\mathrm{LD}_{50}$ of $37.4 \mathrm{mg} . / \mathrm{kg}$. for TML given to rats subcutaneously 
in absolute alcohol. The animals showed hyperexcitability, quiverings, and finally paresis of the back limbs 30 hours after administration of TML.

Ethylene Dibromide and Ethylene Dichloride.These are halogenated hydrocarbons used in industry for their excellent solvent properties. They are highly toxic. The symptoms observed after exposure to these compounds are irritation of the conjunctiva, respiratory tract, and digestive system resulting in lacrimation, salivation, and respiratory difficulties. Initially there is some degree of motor excitation and finally narcosis and bulbar paralysis.

Experimentally, mice exposed for 50 minutes to ethylene dibromide vapour at a concentration of $66 \mathrm{mg}$./l. air die one to two days later. The lethal subcutaneous dose is $1600 \mathrm{mg}$. $/ \mathrm{kg}$. for rabbits and for mice $910 \mathrm{mg} . / \mathrm{kg}$. per os. Mice exposed to ethylene dichloride at a concentration of $23 \mathrm{mg}$./l. for 70 minutes die during the exposure. If exposure lasts for 54 minutes they die the following day (Patty, 1949).

Toluene.-The toxicity of toluene is well known. The lethal doses vary from 4300 to $8600 \mathrm{mg} . / \mathrm{kg}$. subcutaneously and 30 to $45 \mathrm{mg}$./1. by inhalation. The toxic action results in the depression of the central nervous system.

The TML mixture, adopted by some industries and used in these experiments, contains the abovementioned compounds in the proportions given in Table 1. The possible interference of the different compounds with their different mechanisms of action and the different tissues affected cause a high variability in the biological effects of the mixture. This becomes particularly evident for doses between the extreme limits; that is, doses with an immediate lethal effect and doses with limited toxic effect.

Experimentally (see Tables 2 and 3) the relation between the biological effect and the dose administered is not always clear, at least for certain doses, e.g. 600 to $800 \mathrm{mg} . / \mathrm{kg}$. when given subcutaneously and 12 to $36 \mathrm{~g} . / \mathrm{m}^{3}$ when given by inhalation. However, the correlation of death and dose at different times is significant $(0.02<p<0.05)$ when obtained over the wide dose range of 300 to $800 \mathrm{mg}$. $/ \mathrm{kg}$. The toxicity of the TML mixture to mice when given by subcutaneous injection may have been influenced by the ethyl alcohol used as a diluent since some deaths occurred in animals receiving mixtures of ethyl alcohol and water alone. Nevertheless, the death incidence for ethyl alcohol and water mixtures was considerably less than that for the TML mixture diluted with alcohol.

The initial signs observed in animals after administration of medium doses of the TML mixture may be interpreted as a cortical excitation effect; subsequently, and always with higher doses, an inhibitory effect occurs, which is particularly evident in mice intoxicated by inhalation.

Limiting our findings to the toxic effects observed after giving high doses it is concluded that the TML mixture has a low toxicity.

\section{REFERENCES}

Cremer, J. E. (1959). Brit. J. industr. Med., 16, 191.

, and Callaway, S. (1961). ibid., 18, 277.

Patty, F. A. (1949). Industrial Hygiene and Toxicology, Vol. 2. p. 805 and 814. Interscience Publishers, New York.

Salvi, G., and Gherardi, M. (1961). Folia med. (Napoli), 44, 983.

TABLE 3

DEATHS AMONG MICE EXPOSED TO THE VAPOUR OF TML MIXTURE

\begin{tabular}{|c|c|c|c|c|c|c|c|c|c|c|c|c|c|c|c|c|c|c|c|c|c|c|c|c|c|c|}
\hline \multirow{2}{*}{$\begin{array}{l}(\mathrm{g} .1 \\
\left.\mathrm{m} \cdot{ }^{3}\right)\end{array}$} & \multicolumn{11}{|c|}{ Time After Exposure (hours) } & \multicolumn{15}{|c|}{ Time After Exposure (days) } \\
\hline & 6 & 24 & 36 & 48 & 60 & 72 & 84 & 96 & 108 & 120 & 132 & 6 & 7 & 8 & 9 & 10 & 11 & 12 & 13 & 14 & 15 & 16 & 17 & & & \\
\hline $\begin{array}{c}<40 \\
\sim 36 \\
\sim 24 \\
\sim 12 \\
\sim \\
\quad 8 \cdot 3 \\
\quad 6\end{array}$ & $\begin{array}{l}3 / 9 \\
3 / 9 \\
2 / 9 \\
0 / 9 \\
0 / 9 \\
0 / 9\end{array}$ & $\begin{array}{l}5 / 9 \\
3 / 9 \\
3 / 9 \\
3 / 9 \\
0 / 9 \\
0 / 9\end{array}$ & $\begin{array}{l}9 / 9 \\
4 / 9 \\
5 / 9 \\
5 / 9 \\
1 / 9 \\
0 / 9\end{array}$ & $\begin{array}{l}7 / 9 \\
9 / 9 \\
8 / 9 \\
2 / 9 \\
0 / 9\end{array}$ & $\begin{array}{l}9 / 9 \\
9 / 9 \\
2 / 9 \\
0 / 9\end{array}$ & $\begin{array}{l}3 / 9 \\
0 / 9\end{array}$ & $\begin{array}{l}3 / 9 \\
0 / 9\end{array}$ & $\begin{array}{l}3 / 9 \\
1 / 9\end{array}$ & $\begin{array}{l}3 / 9 \\
1 / 9\end{array}$ & $\begin{array}{l}5 / 9 \\
1 / 9\end{array}$ & $\begin{array}{l}5 / 9 \\
1 / 9\end{array}$ & $\begin{array}{l}5 / 9 \\
2 / 9\end{array}$ & $5 / 9$ & $6 / 9$ & $\mid \begin{array}{l}6 / 9 \\
2 / 9\end{array}$ & $\begin{array}{l}6 / 9 \\
2 / 9\end{array}$ & $\begin{array}{l}7 / 9 \\
3 / 9\end{array}$ & $\begin{array}{l}7 / 9 \\
3 / 9\end{array}$ & $\begin{array}{l}9 / 9 \\
4 / 9\end{array}$ & $4 / 9$ & $4 / 9$ & $4 / 9$ & $5 / 9$ & & & \\
\hline 2 & $0 / 9$ & $0 / 9$ & $0 / 9$ & $0 / 9$ & $0 / 9$ & $0 / 9$ & $0 / 9$ & $0 / 9$ & $0 / 9$ & $1 / 9$ & 1/9 & $2 / 9$ & $2 / 9$ & $3 / 9$ & $3 / 9$ & $3 / 9$ & $4 / 9$ & $5 / 9$ & $5 / 9$ & $5 / 9$ & $5 / 9$ & $5 / 9$ & $6 / 9$ & 7/9 (19) & $8 / 9$ day) & 9/9 (22nd \\
\hline $1 \cdot 2$ & $0 / 6$ & $0 / 6$ & $0 / 6$ & $0 / 6$ & $0 / 6$ & $0 / 6$ & $0 / 6$ & $0 / 6$ & $0 / 6$ & $0 / 6$ & $0 / 6$ & $1 / 6$ & $1 / 6$ & $1 / 6$ & $1 / 6$ & $1 / 6$ & $1 / 6$ & $1 / 6$ & $1 / 6$ & $1 / 6$ & $1 / 6$ & $1 / 6$ & $1 / 6$ & $\begin{array}{c}\text { day) } \\
2 / 6 \text { (19th } \\
\text { day) }\end{array}$ & $\begin{array}{l}\text { day) } \\
3 / 6 \text { (26th } \\
\text { day) }\end{array}$ & $\begin{array}{l}\text { day) } \\
4 / 6 \text { (30th } \\
\text { day) }\end{array}$ \\
\hline
\end{tabular}

